\title{
Potable Water Savings in Multifamily Buildings Using Stormwater Runoff from Impermeable Paved Streets
}

\author{
Liseane Padilha Thives ${ }^{1}$, Enedir Ghisi ${ }^{1}$, Natália Mattos da Silva ${ }^{1}$
}

\begin{abstract}
Currently, due to the imbalance between demand and supply of water, a short-term possibility of water resources scarcity is a challenge to be faced in several countries. This subject has been a matter of concern for researchers, governments, regulators, and water suppliers. The enforcement of sustainable measures, such as the use of rainwater in buildings, is an alternative to ease the problem; however, the use of stormwater in buildings should also be assessed. The objective of this work is to estimate the potential for potable water savings in multifamily buildings through the use of stormwater runoff collected from paved streets. A case study was carried out, based on actual buildings and catchment areas of urban streets in the city centre of Florianópolis, a city located in southern Brazil. Stormwater runoff is meant to be used for non-potable purposes such as toilet flushing, washing machines, and cleaning. Computer simulations were performed using the Netuno computer programme, version 4. Three scenarios of water consumption were simulated (120, 160 and $200 \mathrm{~L} /$ person.day). A paved area equal to $9,058 \mathrm{~m}^{2}$ and a rainwater tank capacity of $1,000 \mathrm{~m}^{3}$ were obtained. The potential for potable water savings ranged from $16.91 \%$ to $33.39 \%$ according to the water demand for non-potable purposes. The use of stormwater runoff harvested from paved streets can be an alternative to save potable water in buildings as well as contribute to a sustainable urban drainage.
\end{abstract}

Keywords: potable water; buildings; stormwater; runoff; paved streets; computer simulation.

\section{Introduction}

About $75 \%$ of the surface of the Earth is covered with water, and the oceans hold $96.5 \%$ of all water. Only 3.5\% is freshwater (United States Geological Survey [USGS] (2017), United Nation Educational, Scientific and Cultural Organization [UNESCO] (2017)). Global annual water use will grow around 10 to 12\% every decade due to population growth and industrialization (McIntire, 2012). The growing water demand and the possibility of water resources scarcity is a challenge to be faced in several countries. This subject has been a source of concern for researchers, governments, regulators, and water suppliers.

According to the Brazilian Water Agency [ANA] (2010), domestic water in Brazil is supplied by surface water and groundwater, in which $47 \%$ are exclusively provided by surface water sources, $39 \%$ by groundwater and $14 \%$ by both types, mixed supply. Also, around $55 \%$ of the municipalities have deficient water supplies and need to seek environmental solutions to problems in their supply systems.

In Brazil, 85\% of the population lives in urban areas (Instituto Brasileiro de Geografia e Estatistica [IBGE], (2010)). The growing and disordered urbanization has been changed the land use pattern. As a consequence, the number of impermeable areas also increased. These, associated with deficient drainage systems and the high incidence of rainfall

${ }^{1}$ Federal University of Santa Catarina, Department of Civil Engineering, Laboratory of Energy Efficiency in Buildings, Florianópolis-SC, Brazil. 
events have caused great urban floods. Especially in southern Brazil, frequent floods in urban areas have resulted in human deaths; increase of diseases (leptospirosis, dengue fever, Zika virus) and also in severe economic impacts.

The excessive stormwater runoff over polluted areas can result in the contamination of groundwater and surface water. However, the contaminants can be removed using some technologies (Hardy, Cubillo, Han \& Li, 2015).

Rainwater can be used both for potable purposes (after properly treated) and nonpotable purposes (toilet flushing, urinals, household cleaning, car wash and in garden irrigation). The feasibility of water recycling projects can be evaluated considering expected savings, health, economic, and environmental issues (Kumarasamy \& Dube, 2016). One of the obstacles to rainwater usage is irregular rainfall distribution over the year in many areas. Rainwater is not feasible in places with shortage of rainfall during the dry season (Hardy et al., 2015). Struck (2011) states that it is also important to identify health risks associated with specific non-potable water uses.

Nowadays, water resources management is very important, once the scarcity of water mainly harms social improvements. In addition, water management is an important scientific issue because there is a need to constantly search means to assure the availability of good-quality water and to preserve such resource (Araújo, Alves, Chrispim, Mendes \& Silva, 2015).

Several studies have shown that harvested rainwater can be used for many purposes, being essential to water resources management; it is also an alternative to face the water scarcity on the planet and reduce flood risks in the cities (Muthukumaran, Baskaran \& Sexton, 2011; Souza \& Ghisi, 2012; Stec \& Kordana, 2015; Devkota, Schlachter \& Apul, 2015; Antunes, Thives \& Ghisi, 2016). The use of rainwater reduces pressure on public water systems, on the groundwater, and also on freshwater from rivers and lakes.

Stormwater harvested from permeable pavements can also allow for potable water savings and runoff reduction. Stormwater can be absorbed by the porous surface of the permeable pavement and drained to a reservoir, which temporarily stores the stormwater before infiltrating it into the soil. This can reduce stormwater runoff volume by $73 \%$ to $99 \%$, which in turn reduces the pollutants carried to water bodies (NRDC, 2011). Permeable pavement systems are suitable for a wide variety of residential, commercial and industrial applications, despite their infrequent use (Scholz \& Grabowiecki, 2006).

In this scenario, the objective of this study is to estimate the potential for potable water savings in multifamily buildings through the use of stormwater runoff collected from streets paved with conventional pavement, i.e., impermeable surfaces.

\section{Water Consumption}

According to ANA (2010), the water consumption in Brazil depends on the geographic region, social class, and income. In relation to the geographic region, the water consumption varies from $118.9 \mathrm{~L} /$ person.day in the Northeast (semi-arid region) to 187.9 $\mathrm{L} /$ person.day in the Southeast (most populous region) (Sistema Nacional de Informaçôes sobre Saneamento [SNIS] (2016)). The average water consumption in Brazil is $162 \mathrm{~L} /$ person.day (Hafner, 2007; SNIS, 2016). For the main sectors, the distribution is $46 \%$ agricultural use; $26 \%$ urban consumption and 18\% industrial consumption (ANA, 2007). 
In Florianópolis, the Building and Construction Code and the Law no. 1231 (2016) states that all new commercial and residential buildings with a floor plan area greater than 200 $\mathrm{m}^{2}$ must have rainwater harvesting systems for non-potable uses. The average water consumption in Florianópolis is $186 \mathrm{~L} /$ person.day (Companbia Catarinense de Aguas e Saneamento [CASAN] (2017)).

\section{Methodology}

The methodology to estimate the potential for potable water savings in multifamily buildings through the use of stormwater runoff collected from paved streets was carried out in three phases, as shown in Fig. 1 and described as follows.

\subsection{Data from the Study Area}

The study area is located in the city of Florianópolis, southern Brazil (Fig. 2). Florianópolis is an island located between the latitudes $27^{\circ} 10^{\prime}$ and $27^{\circ} 50^{\prime}$ South and the meridians $48^{\circ} 20^{\prime}$ and $48^{\circ} 35^{\prime}$ West longitude. Rainfall is significant and well-distributed throughout the year. Florianópolis has no dry season; the highest rainfall occurs over the summer. The study area was selected based on data obtained from the Brazilian Institute of Geography and Statistics (IBGE) that keeps data on size and number of households. The place selected for analysis has a total area of $46,392.48 \mathrm{~m}^{2}$ in which the water use scenarios were established. This area entails commercial, public and residential buildings. Once the object of this study is the residential sector, the number of households (single and multifamily) was obtained from IBGE (2010).

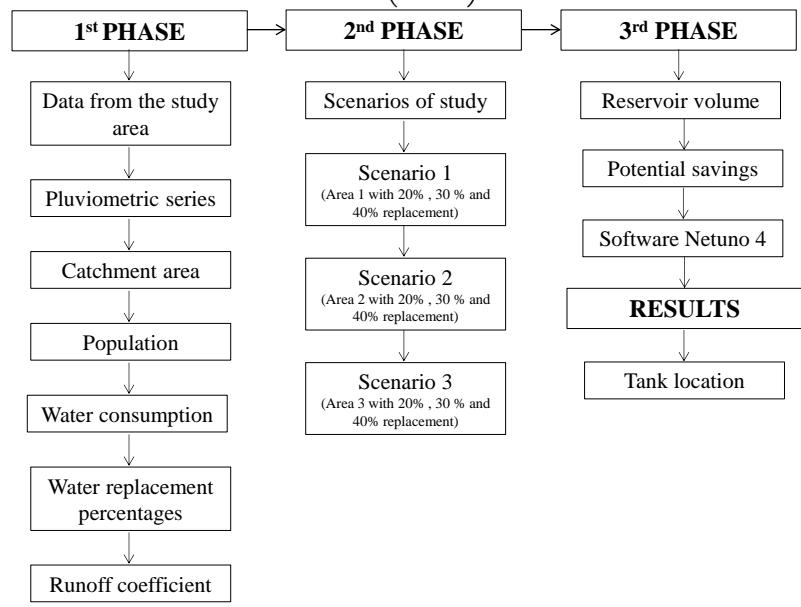

Fig. 1. Flowchart of the method.

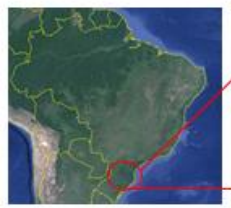

(a) Brazil

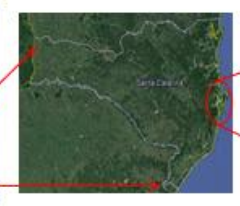

(b) Santa Catarina State

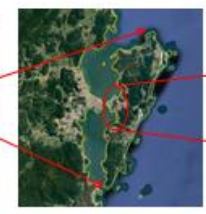

(c) Florianópolis

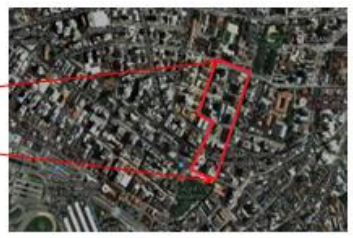

(d) Study area

Fig. 2. Maps indicating the location of the study area. 


\subsection{Rainfall Data}

Rainfall data were obtained from a meteorological station located in Florianópolis. A series of daily rainfall data over 16 years, from 01/01/2000 to 03/05/2016, was used. Fig. 3(a) presents the annual rainfall over 2000-2015 and Fig. 3(b) shows the monthly rainfall for 2015 .

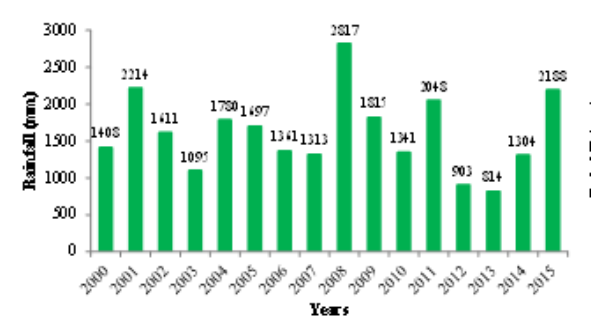

(a) Annual rainfall over 2000 to 2015

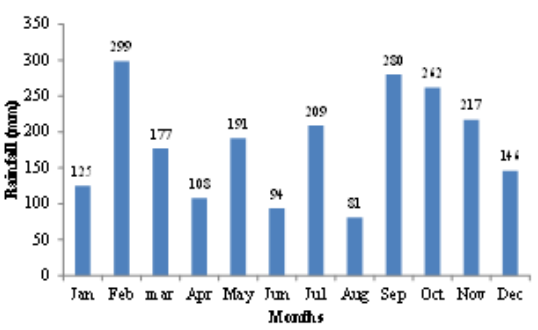

(b) Monthly rainfall in 2015

Fig. 3. Rainfall data for Florianópolis over 2000-2015.

Over 2000-2015, daily average rainfall was $4.75 \mathrm{~mm} /$ day, monthly average rainfall was $146 \mathrm{~mm} /$ month and annual average rainfall was 1,607 mm. From the data, it is observed that the rainfall is significant throughout the years, being favourable to the use of rainwater harvesting systems.

\subsection{Catchment Area}

The catchment area considered is related to the horizontal projection of the impermeable streets paved with asphalt mixtures. The horizontal projection area (Fig. 4) was calculated through the geoprocessing data that resulted in 9,058 $\mathrm{m}^{2}$. From an average error, $\pm 10 \%$, three areas were considered for the analysis as shown in Table 1 .

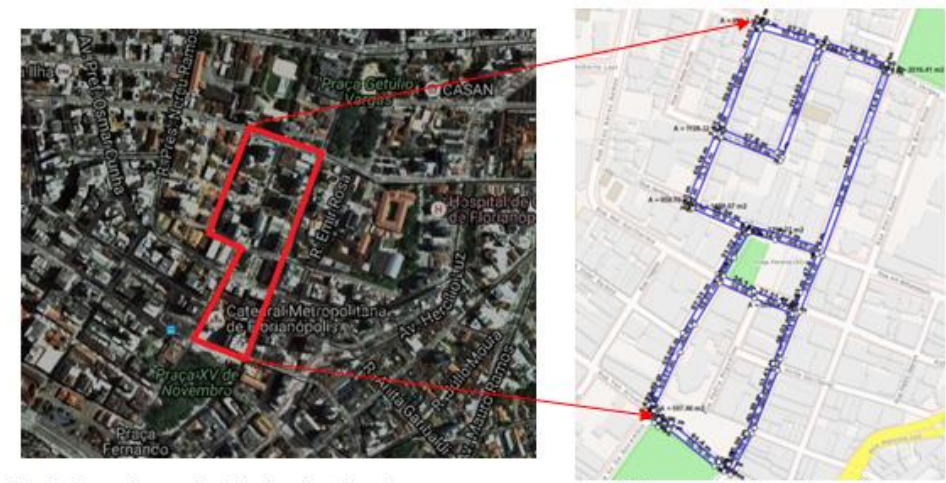

(a) Selected area in Florianópolis city centre

(b) Streets in the selected area

Fig. 4. Catchment area for stormwater harvesting.

Table 1. Areas considered for stormwater harvesting.

\begin{tabular}{clc}
\hline Area name & Description & Area $\left(\mathrm{m}^{2}\right)$ \\
\hline A1 & Catchment area $-10 \%$ & 8,152 \\
A2 & Catchment area & 9,058 \\
A3 & Catchment area $+10 \%$ & 9,964 \\
\hline
\end{tabular}




\subsection{Population}

The Brazilian last census was conducted in 2010. In order to obtain data for 2016 population growth rates of the municipality were applied. In the selected area, according to IBGE census data, there are 262 flats, in which, 719 inhabitants live.

\subsection{Water Consumption}

The water consumption was obtained from data measured in Florianópolis (Vieira, 2013, Dalsenter, 2016), provided by SNIS (2016) and from Building Code of the city (Prefeitura Municipal de Florianópolis [PMF], (2011). Such consumption ranges from 124 $\mathrm{L} /$ inhab.day to $200 \mathrm{~L} /$ inhab.day. Thus, three water consumption scenarios were considered in this study: (i) minimum, 120 L/inhab.day; (ii) average, $160 \mathrm{~L} /$ inhab.day; (iii) maximum, $200 \mathrm{~L} /$ inhab.day.

\subsection{Water Demand for Non-potable Purposes}

The water demand for non-potable purposes in the residential sector was obtained from the literature. The demand considered includes toilet flushing, washing clothes by hand, washing machine and general cleaning. Based on the data from Barreto (2008), Dalsenter (2016), and Proença, Ghisi, Tavares \& Coelho (2011), three scenarios for water demand for non-potable purposes were chosen, i.e., $20 \%, 30 \%$ and $40 \%$ of the water demand.

\subsection{Stormwater Runoff}

The runoff coefficient for paved roads with dense asphalt mixtures (impermeable surfaces) ranges from 0.875 to 0.950 (Souza, Santos, Rios, Silva, Azevedo \& Batista (2012); Tucci (2000)). Therefore, a runoff coefficient equal to 0.90 was considered.

\subsection{Computer Simulations}

For three study scenarios, twenty-seven simulations were performed. In all the scenarios, nine simulations were performed for each of the three daily water consumptions, having as variables: three non-potable water demands and three catchment areas.

The calculations to obtain the potential for potable water savings were performed using the computer programme Netuno version 4 (Ghisi \& Cordova, 2014). Input data for the simulations are: (i) daily rainfall $(\mathrm{mm})$; (ii) catchment area $\left(\mathrm{m}^{2}\right)$; (iii) number of residents; (iv) total potable water demand (L/inhab.day); (v) water demand for non-potable purposes (as a percentage of the total potable water demand); (vi) runoff coefficient; and (vii) upper stormwater tank.

The estimation of the lower stormwater tank capacity was carried out considering several volumes, using intervals of 100,000 litres, until reaching the maximum volume of 10,000,000 litres. The qualitative analysis for the selection of the ideal tank capacity took into account a volume in which the difference among rainwater potentials in the scenarios presented very small variations with each increment of tank capacity. 


\section{Results}

The input data used in the simulations for the three scenarios are presented in Table 2. The potential for potable water savings obtained from the computer simulations are shown in Fig. 5.

Table 2. Input data used in the computer simulations.

\begin{tabular}{llll}
\hline Data & Variables & \\
\hline Rainfall (years) & 2000 to 2016 & \\
Number of days considered in the simulations & 5,967 & & \\
Paved streets catchment areas $\left(\mathrm{m}^{2}\right)$ & 8,152 & 9,058 & 9,964 \\
Runoff coefficient & 0.9 & & \\
Inhabitants & 719 & & \\
Rainwater demand for non-potable purposes (\%) & 20 & 30 & 40 \\
Water demand (L/inhab.day) & 120 & 160 & 200 \\
Maximum tank capacity (L) & $10,000,000$ & \\
Increment between tank capacities (L) & 100,000 & \\
\hline
\end{tabular}

From Fig. 5 it can be observed that there is no great increment in the potential for potable water savings for tank capacities greater than 1,000,000 litres. For example, considering a water demand equal to $120 \mathrm{~L} /$ inhab.day, paved area equal to A1 and nonpotable water demand equal to $20 \%$ of the water demand, the potential savings are equal to $19.55 \%$ using a $2,000,000-\mathrm{L}$ tank, while such savings equal $19.03 \%$ for a $1,000,000-\mathrm{L}$ tank. Thus, the potential savings increase only $0.52 \%$ by increasing the tank capacity in 1,000,000 litres. Therefore, adopting a 2,000,000-L tank would not lead to significant increment in the savings. A stormwater tank capacity equal to 1,000,000 litres proved to be the ideal for all scenarios analysed herein. Table 3 shows the potential for potable water savings for a stormwater tank capacity equal to 1,000,000 litres.

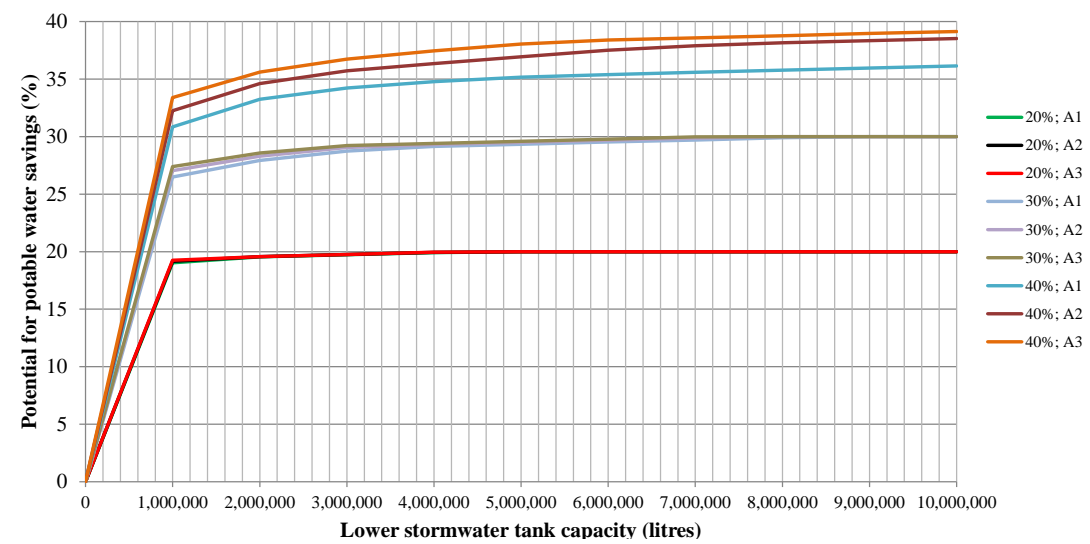

(a) Water consumption equal to $120 \mathrm{~L} /$ inhab.day 


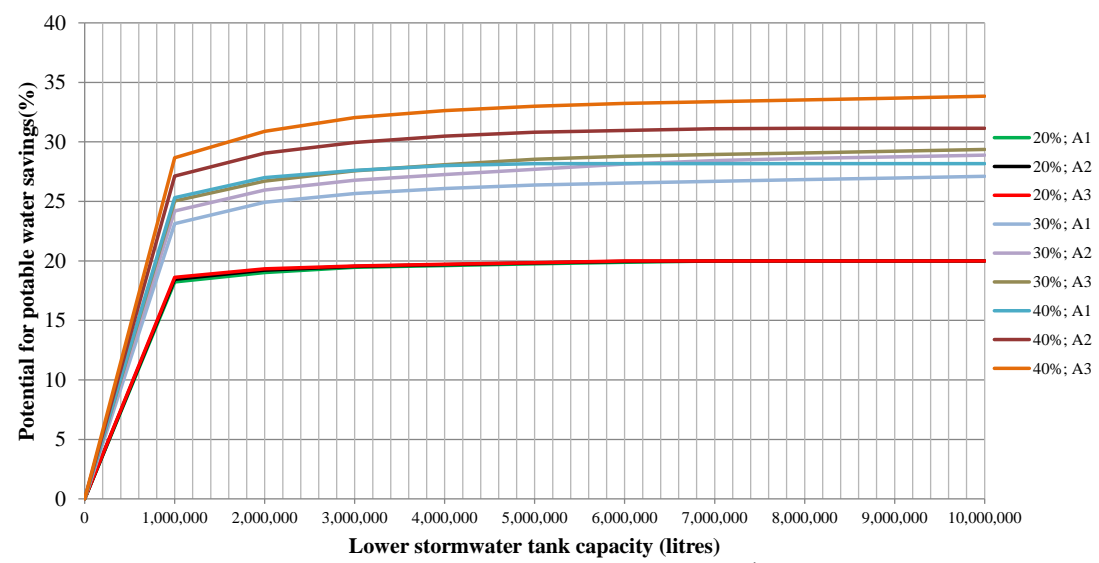

(b) Water consumption equal to $160 \mathrm{~L} /$ inhab.day

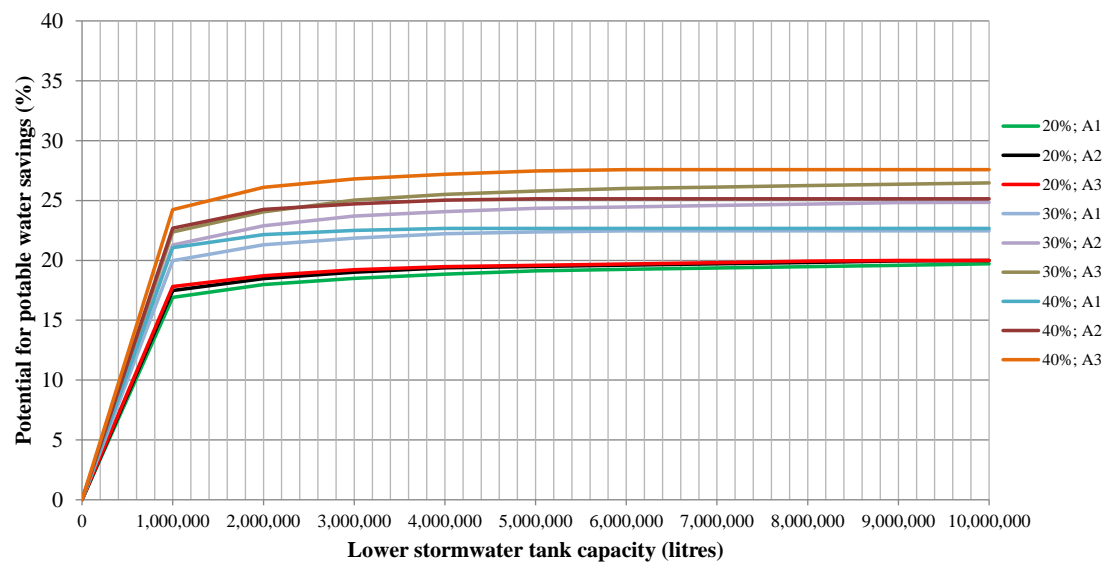

(c) Water consumption equal to $200 \mathrm{~L} /$ inhab.day

Fig. 5. Potential for potable water savings considering non-potable water demands equal to 20\%, 30\%, 40\% and paved street areas equal to $A 1, A 2, A 3$.

Table 3. Potential for potable water savings considering a stormwater tank capacity equal to $1000 \mathrm{~m}^{3}$.

\begin{tabular}{|c|c|c|c|c|c|}
\hline \multirow[b]{2}{*}{$\begin{array}{l}\text { Catchment } \\
\text { area }\left(\mathrm{m}^{2}\right)\end{array}$} & \multirow{2}{*}{$\begin{array}{l}\text { Water demand } \\
\text { for non-potable } \\
\text { purposes }(\%)\end{array}$} & \multicolumn{3}{|c|}{ Potable water savings (\%) } & \multirow{2}{*}{$\begin{array}{l}\text { Stormwater to } \\
\text { supply the non- } \\
\text { potable demand }(\%)\end{array}$} \\
\hline & & $\begin{array}{c}120 \\
\text { (L/inhab.day) }\end{array}$ & $\begin{array}{c}160 \\
\text { (L/inhab.day) }\end{array}$ & $\begin{array}{c}200 \\
\text { (L/inhab.day) }\end{array}$ & \\
\hline A1 & \multirow{3}{*}{20} & 19.03 & 18.24 & 16.91 & \multirow{3}{*}{$84.55-96.30$} \\
\hline A2 & & 19.16 & 18.45 & 17.48 & \\
\hline A3 & & 19.26 & 18.61 & 17.81 & \\
\hline A1 & \multirow{3}{*}{30} & 26.48 & 23.13 & 19.67 & \multirow{3}{*}{$65.57-91.33$} \\
\hline A2 & & 27.04 & 24.19 & 21.29 & \\
\hline A3 & & 27.40 & 25.04 & 22.37 & \\
\hline A1 & \multirow{3}{*}{40} & 30.84 & 25.31 & 21.06 & \multirow{3}{*}{$52.65-83.47$} \\
\hline A2 & & 32.25 & 27.13 & 22.68 & \\
\hline A3 & & 33.39 & 28.67 & 24.23 & \\
\hline
\end{tabular}


From Table 3 it was observed that considering a stormwater tank capacity equal to $1000 \mathrm{~m}^{3}$ :

- For non-potable water demand equal to $20 \%$ of the water demand, the potential for potable water savings ranged from $16.91 \%$ to $19.26 \%$. Therefore, there would be enough stormwater to supply $84.55-96.30 \%$ of the non-potable water demand;

- For non-potable water demand equal to $30 \%$ of the water demand, the potential for potable water savings ranged from $19.67 \%$ to $27.40 \%$. Therefore, there would be enough stormwater to supply $65.57-91.33 \%$ of the non-potable water demand;

- For non-potable water demand equal to $40 \%$ of the water demand, the potential for potable water savings ranged from $21.06 \%$ to $33.39 \%$. Therefore, there would be enough stormwater to supply $52.65-83.47 \%$ of the non-potable water demand.

From previous studies that assessed the potential for potable water savings in three multifamily buildings in Florianópolis by using rainwater collected from their roofs, savings ranging from $14.7 \%$ to $17.7 \%$ were obtained (Ghisi \& Ferreira, 2007). Dalsenter (2016) obtained savings ranging from $7.21 \%$ to $8.42 \%$ in three other multifamily buildings. Therefore, collecting stormwater runoff from paved roads would lead to potable water savings higher than those obtained from rooftop rainwater.

The location of the stormwater tank should be close to the lowest point of the drainage basin in order to collect the stormwater runoff by gravity. It was observed that one of the lowest points in the study area is located in a square opposite to the City Cathedral. Fig. 6 shows the study area with the location of the stormwater tank and the stormwater runoff flowing towards the tank. Underneath the square there is space for placing a stormwater tank measuring $10 \mathrm{~m}$ x $50 \mathrm{~m} \times 2 \mathrm{~m}$ which results in a capacity equal to $1000 \mathrm{~m}^{3}$. Fig. 7 shows a view of the square and the stormwater tank. Then, stormwater will be pumped from that tank to non-potable water tanks located in each multifamily building.

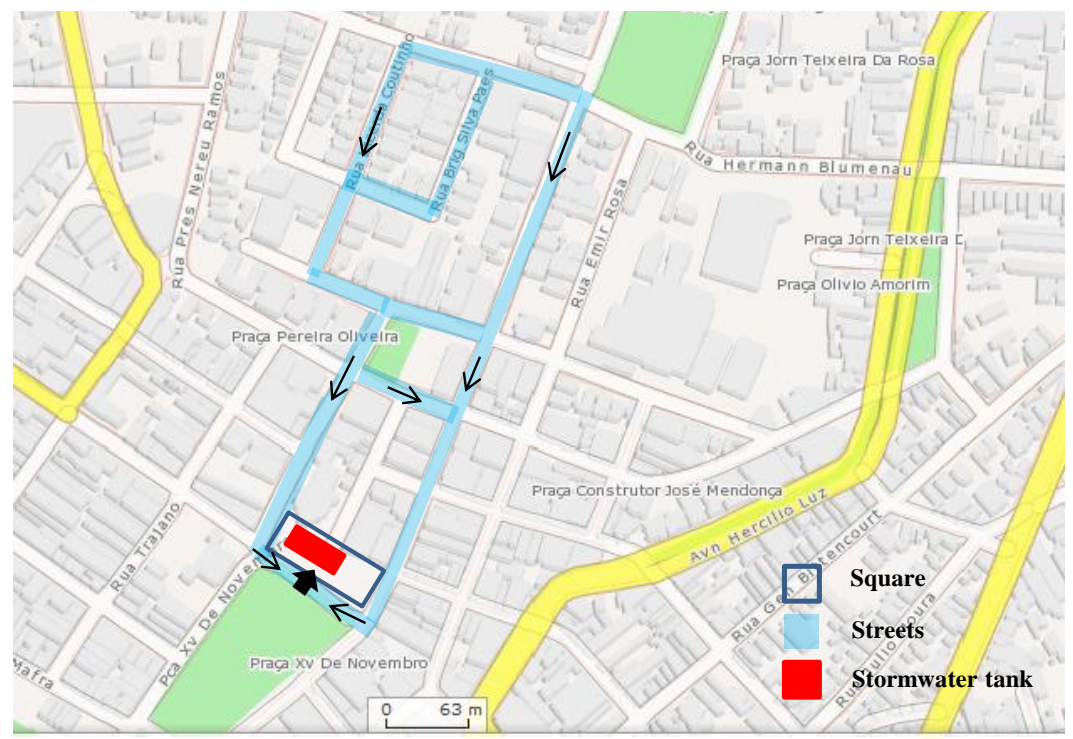

Fig. 6. Map showing the location of the stormwater tank (Based on PMF, 2016). 


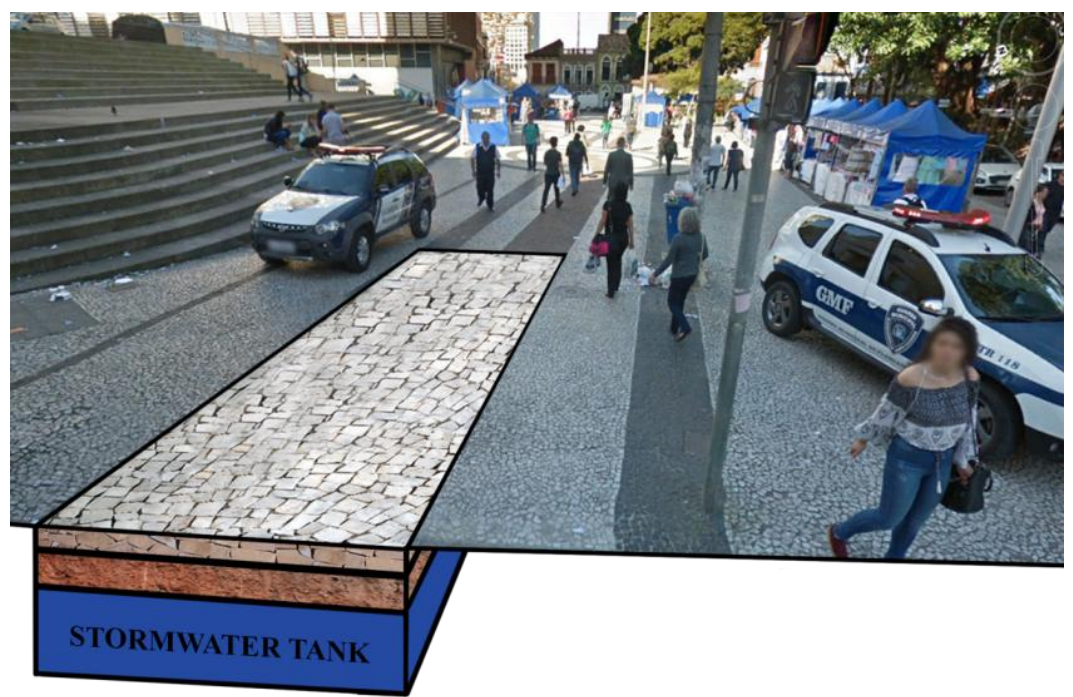

Fig. 7. View of the square and the stormwater tank.

\section{Conclusion}

The objective of this work was to estimate the potential for potable water savings in multifamily buildings through the use of stormwater runoff collected from paved streets for non-potable purposes. Thus, an area in the city centre of Florianópolis, southern Brazil, was evaluated using real data from paved streets area, population and buildings.

For stormwater tank capacities greater than $1000 \mathrm{~m}^{3}$, there was little increase in the potential for potable water savings. Thus, a stormwater tank capacity equal to $1000 \mathrm{~m}^{3}$ was considered as ideal. Comparing the potable water savings obtained from all simulations, it was concluded that the lower the water consumption, the greater the potential for potable water savings.

In general, the potential for potable water savings by using stormwater runoff collected from streets in Florianópolis would range from 16.91\% to $33.39 \%$ for non-potable water demands ranging from $20 \%$ to $40 \%$ of the water demand. And there would be enough stormwater to supply $52.65-96.30 \%$ of the non-potable water demand.

The results obtained in this work showed that collecting stormwater runoff from paved streets or roads can be an interesting alternative for saving potable water in buildings, besides contributing to a sustainable urban drainage. The quality of such stormwater and an investment feasibility analysis are also matters of concern, but they were not addressed in this work.

\section{Acknowledgments}

The authors would like to thank Igor Catão Martins Vaz for drawing Fig. 7. 


\section{References}

Antunes, L. N., Thives, L. P., \& Ghisi. E. (2016). Potential for potable water savings in buildings by using stormwater harvested from porous pavements Water, 8, 1-18.

Araújo, R . S., Alves, M. G., Melo, M. T. C. de, Chrispim, Z. M. P., Mendes, M. P.\& Silva, G. C. Júnior. (2015) Water resource management: a comparative evaluation of Brazil, Rio de Janeiro, the European Union and Portugal. Science of The Total Environment, 511(1), 815-828.

Barreto, D. (2008). Perfil do consumo residencial e usos finais da água. Ambiente Construído, 8, 2, 23-40.

Brazilian National Agency of Water. (2010). Atlas Brasil. Retrieved November 15, 2016, from http://atlas.ana.gov.br/Atlas/forms/Home.aspx

Brazilian National Agency of Water. (2010). Disponibilidade e demanda de recursos hidricos no Brasil. Caderno de Recursos Hidricos. Retrieved September 12, 2016, from http://arquivos.ana.gov.br/institucional/sge/CEDOC/Catalogo/2007/DisponibilidadeEDeman dasBrasil.pdf

Companhia Catarinense de Águas e Saneamento (2017). Retrieved February 5, 2018, from http://www.casan.com.br/noticia/index/url/continuidade-da-estiagem-mantem-alerta-parareducao-do-consumo-de-agua $\# 0$

Dalsenter, M. E. V. (2016). Estudo de potencial de economia de água potável por meio do aproveitamento de água pluvial em um condomínio residencial localizado em Florianópolis - SC. Trabalho de Conclusão de Curso. Universidade Federal de Santa Catarina. Florianópolis, SC, Brasil.

Devkota, J., Schlachter, H. \& Apul, D. (2015). Life cycle based evaluation of harvested rainwater use in toilets and for irrigation. Journal of Cleaner Production, 95, 311-321.

Ghisi, E. \& Cordova, M. M. (2014). Netuno 4 - Manual do Usuário. Laboratório de Eficiência Energética em Edificações, Universidade Federal de Santa Catarina. Florianópolis, SC, Brasil.

Ghisi, E. \& Ferreira, D. F. (2007). Potential for potable water savings by using rainwater and greywater in a multi-storey residential building in southern Brazil. Building and Environment, 42, 2512-2522.

Hafner, A. V. (2007). Conservação e reuso de água em edificações - experiências nacionais e internacionais. Dissertação de Mestrado. Programa de Pós-Graduação em Engenharias da Universidade Federal do Rio de Janeiro. Rio de Janeiro, RJ, Brasil.

Hardy, D.; Cubillo, F.; Han, M. \& Li, K. (2015). Alternative water resources: a review of concepts, solutions and experiences. International Water Association (IWA), Alternative Water Resources Cluster, London, United Kingdom.

Instituto Brasileiro de Geografia e Estatística (2010). Censo demográfico. Retrieved March 12, 2016, from https://www.ibge.gov.br/estatisticas-novoportal/sociais/populacao/2098-np-censo demografico/9662-censo-demografico-2010.html

Kammers, P. C. \& Ghisi, E. (2006). Usos finais de água em edifícios públicos localizados em Florianópolis, SC. Ambiente Construído, 6(1), 75-90.

Kumarasamy, M. V. \& Dube, V. N. (2016). Study on recycling urban wastewater for non-potable uses for water conservation. Polish Journal of Environmental Studies, 25(1), 167-171.

Lei no. 1231 de 01 de fevereiro de 2016 (2016). Estabelece alteração no código de obras e Edificações de Florianópolis ao determinar que todas as novas edificações comerciais e residenciais com área acima de $200 \mathrm{~m}^{2}$ construídas no município deverão ter captação das águas de chuva para reuso de forma obrigatórias. Florianópolis, SC, Brasil: Prefeitura Municipal.

McIntire, D. (2012). Conserves water overseas. U.S. Department of State. State Magazine, 566. Retrieved October 20, 2016, from https://www.state.gov/documents/organization/186815.pdf

Muthukumaran, S., Baskaran, K. \& Sexton, N. (2011). Quantification of potable water savings by residential water conservation and reuse - A case study. Resources, Conservation and Recycling, 55(11), 945-952.

PMF. Prefeitura Municipal de Florianópolis (2011). Plano Municipal Integrado de Saneamento Básico. Retrieved July 11, 2016, from http://portal.pmf.sc.gov.br/arquivos/arquivos/pdf/23_02_2011_14.10.48.ef4fafff9080123c2472 2cf58ca7eb78.pdf

PMF. Prefeitura Municipal de Florianópolis (2016). Geoprocessamento. Retrieved February 14, 2018, from http://geo.pmf.sc.gov.br/ 
Natural Resources Defense Council, (2011). After the storm: how green infrastructure can effectively manage stormwater runoff from roads and highways. NRDC (Natural Resources Defense Council). $\quad$ Retrieved $\quad$ February $\quad$ 5, 2018, from https://www.nrdc.org/sites/default/files/afterthestorm.pdf

Proença, L. C., Ghisi, E., Tavares, D. F. \& Coelho, G. M. (2011). Potential for electricity savings by reducing potable water consumption in a city scale. Resources, Conservation and Recycling, 55(11), 960-965.

Scholz, M. \& Grabowiecki, P. (2006). Review of permeable pavement systems. Building and Environment 42, $3830-3836$.

Sistema Nacional de Informações sobre Saneamento (2016). Diagnóstico dos serviços de água e esgoto - 2014. Ministério das Cidades, Secretaria Nacional de Saneamento Básico, Brasília, DF, Brasil.

Souza, E. L. \& Ghisi, E. (2012). Potable water savings by using rainwater for non-potable uses in houses. Water, 4, 607-628.

Souza, M. C., Santos, D. B., Rios, M. L., Silva, M. D. Neto, Azevedo, D. O. \& Batista, R. O. (2012). Indicadores da qualidade e estimativa de captação de água pluvial em rodovias asfaltadas do Semiárido Baiano. Water Resources and Irrigation Management, 1, 1, 71-80.

Stec, A. \& Kordana, S. (2015) Analysis of profitability of rainwater harvesting, gray water recycling and drain water heat recovery systems. Resources, Conservation and Recycling, 105, 84-94.

Struck, S. (2011). Rainwater harvesting for non-potable use and evidence of risk posed to human health. British Columbia Centre for Disease Control. Retrieved July 11, 2016, from http://www.ccnse.ca/sites/default/files/BCCDC-Rainwater_Harvesting_Oct_2011.pdf

Tucci, C. E. M. (2000). Coeficiente de escoamento e vazão máxima de bacias urbanas. Revista Brasileira de Recursos Hidricos, 5(1), 61-68.

Vieira, A. S. (2012). Uso racional de água em habitações de interesse social como estratégia para conservação de energia em Florianópolis, Santa Catarina. Dissertação de Mestrado. Universidade Federal de Santa Catarina, Florianópolis, SC, Brasil.

United Nation Educational, Scientific and Cultural Organization (2017). The properties and availability of water: a fundamental consideration for life. Drops of water 2. UNESCO. Retrieved February 5, 2018, from http://www.unesco.org/fileadmin/MULTIMEDIA/FIELD/Venice/pdf/special_events/bozza_sc heda_DOW02_1.0.pdf

United States Geological Survey (2017). How much water is there on, in, and above the Earth? USGS. Retrieved February 5, 2018, from https://water.usgs.gov/edu/earthhowmuch.html 